\section{Proofs of ethnic purity advanced}

A MAJOR research project into the present state and future prospects of Bulgarian brain and intellect, carried out at the Institute of Brain Research of the Bulgarian Academy of Sciences, suggests that the modern Bulgarian has a very flexible intellect, but fails to use it to its full potential. According to Dr Ana Vrbanova, the director of the institute, this unsatisfactory situation is caused by poor use and organization of Bulgarian culture and traditions.

\section{EPA expansion urged \\ Washington}

AN advisory panel to the US Environmental Protection Agency (EPA) has concluded that EPA needs to expand its research programme in order to cope with the expected influx of requests to release genetically altered organisms into the environment. The panel says it is impressed with what EPA has done, given the resources at its disposal, but says the agency should do more to establish test protocols for considering environmental releases.

The Study Group on Biotechnology, set up under EPA's congressionally established Science Advisory Board, is a public group intended to provide external review of the agency's actions. The study group was chaired by Martin Alexander, a microbiologist at Cornell University. EPA has not officially responded to the report, but its scientists say they broadly concur with its conclusions. EPA recently approved the first environmental release of genetically engineered microorganisms into the environment, and ran straight into a controversy (see Nature 319, 254; 1986). The agency will shortly be publishing general terms and conditions that it will use for considering such applications.

The study group says an adequate research programme for environmental releases should address survival, growth, genetic tranfer in situ, dispersal, environmental effects, health effects, remedial action and use of biotechnology for destroying pollutants. So far, EPA has examined applications on a case-by-case basis but the study panel says the "absence of generally accepted tests and test methods . . . is cause for concern". The panel observes that EPA has "essentially no program" of research into environmental effects, and says EPA needs increased resources to conduct "innovative research" that will lead to definitive generally accepted test protocols. It also recommends that another special panel be established to provide peer review of EPA's risk-assessment efforts. Tim Beardsley
Reporting on the preliminary results of what is admitted to be a far from complete study, the Bulgarian media have stressed the declaration of a recent Central Committee plenary meeting that "the construction of a developed socialist society not only asks for but also demands the activation of the brain cells"

This premature media coverage is not simply a way of urging Bulgarians in the learned professions to work harder during the new five-year plan, but seems to be related to current political and ethnographic claims of the purity of the Bulgarian nation and, in particular, of the absence of a Turkish ethnic minority.

This emphasis on Bulgarian specificity accords well with the current official Bulgarian view of its Turkish minority. During the past few years, large numbers of Bulgarians of Islamic descent have ("voluntarily", it is claimed) changed their Turkish-sounding given names and surnames to Slavonic names. Protests from Turkey that the changes were being carried out under pressure brought a rejoinder from Sofia that the people concerned were not Turkish at all, but ethnic Bulgarians whose ancestors had been converted to Islam under the Ottoman Empire.

Now the Bulgarian Academy of Sciences has published a monograph, Anthropology of the Bulgarian Nation, said to be based on more than 30 years work by the Institute of Morphology of the Bulgarian Academy of Sciences, using, in particular, anthropometric measurements carried out in areas hitherto thought to contain members of Bulgaria's Turkish and Greek "minorities".

According to a review in the daily Otechestven Front (1 January 1986), the studies revealed so high a degree of homogeneity that the experts conclude that the fusion of Slavonic, Thracian and Asiatic ethnic elements that gave rise to the Bulgarian nation was complete by the end of the tenth century, and that the past 1,000 years of foreign incursions, including centuries of Ottoman rule, have left no ethnic trace whatsoever. Bulgaria's Turkish minority, the reader is left to deduce does not exist.

This remarkable piece of dialectic is not Bulgaria's first effort in political anthropology. In 1978, the Bulgarian Academy produced a monograph Macedonia, which tion did not exist.

The international repercussions of the academy's new monograph too are likely to be acrimonious, particularly in Greece and Turkey. The study of Bulgarian brainpower, although clearly part of the same political stance, will probably have its greatest effect at home, and may possibly set out to prove that the Macedonian na- engender conflict within the Bulgarian scientific establishment. For, according to Dr Vrbanova, the main purpose in studying Bulgarian brain-power is to activate sociologists, psychologists and doctors into finding and developing techniques to expand the potential of "Bulgarian's nine million brains".

Vera Rich

\section{Marine science}

\section{Changes afoot}

PLANS are afoot for changes in the style of British marine research. Even as the House of Lords Select Committee on Science and Technology finished its report (see Nature 319, 351; 1986), the Science and Engineering Research Council (SERC) was preparing to divest itself of its Marine Technology Directorate (MTD). With a $1984-85$ budget of more than $£ 5$ million, it was established over nine years ago to develop academic involvement in marine matters. It achieved this by a system of grants to seven centres mainly in British universities. Within the next few months, the directorate is to be replaced by a separate corporate entity, MTD Ltd, under the aegis of the Fellowship of Engineering (the engineers' equivalent of the Royal Society). SERC will for the next three years provide only one-third of the $£ 300,000$ operating costs, with the balance being raised by subscription by industry and government departments. SERC will also cut its research contribution and hope that industry will plug the gap.

SERC policy is that directorates should be discontinued as in-house activities after a formative period. A.M. Adye, director of MTD, said that he was not aware of any change in SERC plans in response to the House of Lords committee recommendation that an overseeing Marine Board be established within SERC. But he agreed with the main thrust of the report - that there is too much fragmentation of interests and an overview is needed.

Hugh Fish, chairman of the Natural Environment Research Council, supporting his council against the attacks contained in the report, also agreed that greater co-ordination was necessary. But he felt that a better solution could be found than "the bolting-on of a Marine Board . . . to the existing organizations".

Another spoke in the wheel is the Department of Trade and Industry's Marine Technology Committee, which handles the department's marine research budget. This body is just starting the ball rolling in an effort to develop a co-ordinated national programme for ocean resources such as metallic nodules and "soft" energy (excluding hydrocarbons). The main aim is to encourage industrial interest in both these resources and the technological infrastructures needed for their exploitation.

Peter Gambles 